\title{
Article/Artigo
}

\section{Rabies diagnosis and serology in bats from the State of São Paulo, Brazil}

\author{
Diagnóstico e sorologia de raiva em morcegos do Estado de São Paulo, Brasil
}

\author{
Marilene Fernandes de Almeida ${ }^{1}$, Luzia Fátima Alves Martorelli ${ }^{1}$, Miriam Martos Sodré ${ }^{1}$, Ana Paula Arruda \\ Geraldes Kataoka ${ }^{1}$, Adriana Ruckert da Rosa ${ }^{1}$, Maria Lucia de Oliveira ${ }^{1}$ and Elizabeth Amatuzzi ${ }^{1}$
}

\begin{abstract}
Introduction: Bats are one of the most important reservoirs and vectors of the rabies virus in the world. Methods: From 1988 to 2003, the Zoonosis Control Center in São Paulo City performed rabies diagnosis on 5,670 bats by direct immunofluorescent test and mouse inoculation test. Blood samples were collected from 1,618 bats and the sera were analyzed using the rapid fluorescent focus inhibition test to confirm rabies antibodies. Results: Fortyfour $(0.8 \%)$ bats were positive for rabies. The prevalence of rabies antibodies was $5.9 \%$ using $0.5 \mathrm{IU} / \mathrm{ml}$ as a cutoff. Insectivorous bats $(69.8 \%)$ and bats of the species Molossus molossus (51.8\%) constituted the majority of the sample; however, the highest prevalence of antibodies were observed in Glossophaga soricina (14/133), Histiotus velatus (16/60), Desmodus rotundus (8/66), Artibeus lituratus (5/54), Nyctinomops macrotis (3/23), Tadarida brasiliensis (3/48), Carollia perspicillata (3/9), Eumops auripendulus (2/30), Nyctinomops laticaudatus (2/16), Sturnira lilium $(2 / 17)$ and Eumops perotis $(1 / 13)$. The prevalence of rabies antibodies was analyzed by species, food preference and sex. Conclusions: The expressive levels of antibodies associated with the low virus positivity verified in these bats indicate that rabies virus circulates actively among them.
\end{abstract}

Keywords: Rabies. Chiropteran. Diagnostic. Seroprevalence. Brazil.

\section{RESUMO}

Introdução: Morcegos são um dos mais importantes reservatórios e vetores do vírus da raiva no mundo. Métodos: No período entre 1998 e 2003, o Centro de Controle de Zoonoses da Cidade de São Paulo realizou o diagnóstico de raiva em 5.670 morcegos utilizando as técnicas de imunofluorescência direta e inoculação intracerebral em camundongos. Sangue foi coletado de 1.618 espécimes para pesquisa de anticorpos pela técnica de inibição de foco de fluorescência rápida. Resultados: Quarenta e quatro $(0,8 \%)$ morcegos foram positivos para raiva. A prevalência de anticorpos foi de $5,9 \%$ usando $0,5 \mathrm{UI} / \mathrm{ml}$ como ponto de corte. Os morcegos de hábito alimentar insetívoro $(69,8 \%)$ e os morcegos da espécie Molossus molossus $(51,8 \%)$ representaram a maioria da amostra. Entretanto, as mais altas prevalências de anticorpos foram observadas nos morcegos Glossophaga soricina (14/133), Histiotus velatus (16/60), Desmodus rotundus (8/66), Artibeus lituratus (5/54), Nyctinomops macrotis (3/23), Tadarida brasiliensis (3/48), Carollia perspicillata (3/9), Eumops auripendulus (2/30), Nyctinomops laticaudatus (2/16), Sturnira lilium (2/17) e Eumops perotis (1/13). A prevalência de anticorpos foi analisada por espécie, hábito alimentar e sexo. Conclusões: $O$ expressivo nível de anticorpos associado à baixa positividade para o vírus da raiva entre os morcegos estudados indica que o vírus circula ativamente entre morcegos.

Palavras-chaves: Raiva. Quiróptero. Diagnóstico. Soroprevalência. Brasil.

1. Centro de Controle de Zoonoses, Coordenação de Vigilância em Saúde, Prefeitura da Cidade de São Paulo, São Paulo, SP.

Address to: Dra. Marilene Fernandes de Almeida. CCZ/COVISA/Prefeitura de São Paulo. Rua Santa Eulália 86, Santana, 02031-020 São Paulo, SP, Brasil.

Phone: 5511 2251-2666; Fax 5511 2251-2249

e-mail: marilene@prefeitura.sp.gov.br; lenefalmeida@hotmail.com

Received in 14/06/2010

Accepted in 04/11/2010

\section{INTRODUCTION}

In recent decades, there have been frequent case reports of rabies in bats, which are one of the main virus reservoirs in many countries around the world ${ }^{1}$. Several reports have confirmed the rabies virus in both hematophagous and nonhematophagous bats; the former are responsible for rabies outbreaks in Latin America ${ }^{2}$ and the latter for sporadic rabies transmission to humans ${ }^{3,4}$.

Data from the Pan-American Health Organization $(\mathrm{PAHO})^{5}$ revealed 678 reported cases of battransmitted human rabies in Latin America from 1990 to 2010. Considering only the 240 human cases transmitted by bats during the period 19962010, 74\% were transmitted by hematophagous bats, $6.7 \%$ by nonhematophagous bats and in $19.6 \%$, identification of the species was not registered ${ }^{2,5}$.

In Brazil, between 2001 and 2010, 1,305 cases of rabies in bats were notified, 815 (62.5\%) involving nonhematophagous bats, 303 (23.2\%) in hematophagous bats and in 187 (14.3\%) bats, identification of the species was not confirmed ${ }^{5}$. The rabies virus has already been isolated in 41 of the 172 species that live in Brazil ${ }^{6}$.

The purpose of this work was to report the diagnosis of rabies in bats conducted from 1988 to 2003 on samples collected in the State of São Paulo, Brazil and serology for rabies antibodies performed from 1992 to 2003.

\section{METHODS}

From 1988 to 2003, the rabies laboratory of the São Paulo Zoonosis Control Center (CCZ-SP) received 5,834 bats for rabies diagnosis from citizens and other zoonosis centers in the State of São Paulo. Among these, 164 bats were unsuitable for diagnosis (autolysis, alcohol, etc). Diagnosis was performed on the brain of 5,670 bats by fluorescent antibody test $(\mathrm{FAT})^{7}$ and mouse inoculation test $(\mathrm{MIT})^{8}$. 
Of the total number of received bats, 1,618 were alive. After weighting, the bats were anesthetized with ketamine hydrochloride (Ketamina ${ }^{\circledR}$ ), which was injected into the pectoral muscle, considering weight and volume. Blood was collected by cardiac punction of the bats and the sera were analyzed for rabies virus neutralizing antibody (VNA) using the rapid fluorescent focus inhibition test (RFFIT) ${ }^{9}$. The cutoff point was 0.5IU/ML. Euthanasia of the bats was performed in a $\mathrm{CO}_{2}$ chamber following blood collection.

Statistical analysis was performed using the uncorrected Chi square test, contained in the software Epi-Info 6.0 (CDC, Atlanta, GA, USA).

\section{Ethical considerations}

The Scientific Committee of the CCZ-SP authorized all the proceedings performed in this work. The capture of bats was authorized by a Brazilian institution responsible for wild animal care (Instituto Brasileiro do Meio Ambiente, IBAMA).

\section{RESULTS}

\section{Rabies diagnosis}

Forty-four (0.8\%) bats were positive for rabies by FAT and MIT tests among the 5,670 samples analyzed, $45.5 \%$ of these were from City of São Paulo and 54.5\% from another seven cities in the State of São Paulo. The incubation period for MIT ranged from 6 to 29 days (Table 1).

Regarding the circumstances of the location of the 44 positive bats, 24 were captured inside houses or commercial buildings, ten were collected on the ground, three specimens were capture in fruit trees, three bats were captured by mist nets on farms (two Desmodus rotundus and one Carollia perspicillata) and one specimen was captured by children during flight. In three cases, this data was not available.

The rabies-positive bats belonged to three families and 14 species: Vespertilionidae family (19 bats from six species), Molossidae family (16 bats from four species) and Phyllostomidae family (nine bats from four species). Sixteen were males and 28 were females. Rabies positivity year-by-year is presented in Table $\mathbf{1}$.

\section{Rabies serology}

Virus neutralizing antibody prevalence was $5.9 \%$ in the RFFIT test (96 sera
TABLE 1 - Rabies diagnosis in bats, according to species, year, sex and food preference, State of São Paulo, Brazil, 1988 to 2003.

\begin{tabular}{|c|c|c|c|c|c|c|c|}
\hline Year & Total & $\begin{array}{l}\text { Positives } \\
\text { samples }\end{array}$ & $\begin{array}{c}\text { Cities from State } \\
\text { of São Paulo }\end{array}$ & Species identification & Sex & $\begin{array}{c}\text { Food } \\
\text { preference }\end{array}$ & $\begin{array}{c}\text { Positivity } \\
\% \\
\end{array}$ \\
\hline 1988 & 44 & 1 & São Paulo & Nyctinomops macrotis & $\mathrm{F}$ & insectivorous & 2.3 \\
\hline 1989 & 23 & 0 & - & - & - & - & - \\
\hline 1990 & 58 & 1 & São Paulo & Nyctinomops macrotis & $\mathrm{F}$ & insectivorous & 1.7 \\
\hline 1991 & 69 & 0 & - & - & - & - & 0.0 \\
\hline 1992 & 90 & 0 & - & - & - & - & 0.0 \\
\hline 1993 & 113 & 0 & - & - & - & - & 0.0 \\
\hline 1994 & 96 & 1 & Ribeirão Pires & Myotis nigricans & M & insectivorous & 1.0 \\
\hline 1995 & 129 & 1 & Jundiaí & Lasiurus blossevillii & M & insectivorous & 0.8 \\
\hline 1996 & 557 & 1 & Itapira & Carollia perspicillata & $\mathrm{F}$ & frugivorous & 0.2 \\
\hline \multirow[t]{4}{*}{1997} & 643 & 4 & Ribeirão Pires & Histiotus velatus & $\mathrm{F}$ & insectivorous & \\
\hline & & & São Paulo & Lasiurus cinereus & $\mathrm{F}$ & insectivorous & \\
\hline & & & Santa Branca & Desmodus rotundus & M & hematophagous & \\
\hline & & & Mairinque & Histiotus velatus & $\mathrm{F}$ & insectivorous & 0.6 \\
\hline 1998 & 588 & 0 & - & - & - & - & 0.0 \\
\hline \multirow[t]{3}{*}{1999} & 536 & 3 & São Paulo & Tadarida brasiliensis & $\mathrm{F}$ & insectivorous & \\
\hline & & & São Paulo & Myotis nigricans & $\mathrm{F}$ & insectivorous & \\
\hline & & & São Paulo & Tadarida brasiliensis & M & insectivorous & 0.6 \\
\hline \multirow[t]{3}{*}{2000} & 675 & 3 & São Paulo & Artibeus lituratus & $\mathrm{F}$ & frugivorous & \\
\hline & & & Santo André & Artibeus lituratus & M & frugivorous & \\
\hline & & & Cotia & Artibeus lituratus & $\mathrm{F}$ & frugivorous & 0.4 \\
\hline \multirow[t]{2}{*}{2001} & 516 & 2 & São Paulo & Tadarida brasiliensis & M & insectivorous & \\
\hline & & & São Paulo & Histiotus velatus & $\mathrm{F}$ & insectivorous & 0.4 \\
\hline \multirow[t]{15}{*}{2002} & 684 & 15 & Jundiaí & Desmodus rotundus & F & hematophagous & \\
\hline & & & Guarulhos & Eptesicus brasiliensis & $\mathrm{F}$ & frugivorous & \\
\hline & & & São Paulo & Histiotus velatus & F & insectivorous & \\
\hline & & & São Paulo & Histiotus velatus & $\mathrm{F}$ & insectivorous & \\
\hline & & & São Paulo & Histiotus velatus & F & insectivorous & \\
\hline & & & São Paulo & Histiotus velatus & M & insectivorous & \\
\hline & & & Jundiaí & Tadarida brasiliensis & $\mathrm{F}$ & insectivorous & \\
\hline & & & São Paulo & Tadarida brasiliensis & M & insectivorous & \\
\hline & & & Jundiaí & Artibeus lituratus & M & frugivorous & \\
\hline & & & Jundiaí & Artibeus lituratus & $\mathrm{F}$ & frugivorous & \\
\hline & & & São Paulo & Tardarida brasiliensis & M & insectivorous & \\
\hline & & & Santo André & Lasiurus ega & M & insectivorous & \\
\hline & & & Itu & Lasiurus cinereus & $\mathrm{F}$ & insectivorous & \\
\hline & & & São Paulo & Nyctinomops macrotis & M & insectivorous & \\
\hline & & & Jundiaí & Eptesicus furinalis & $\mathrm{F}$ & frugivorous & 2.2 \\
\hline \multirow[t]{12}{*}{2003} & 849 & 12 & Santo André & Myotis $s p$ & $\mathrm{~F}$ & insectivorous & \\
\hline & & & Jundiaí & Tadarida brasiliensis & M & insectivorous & \\
\hline & & & Jundiaí & Myotis nigricans & $\mathrm{F}$ & insectivorous & 1.4 \\
\hline & & & Santo André & Myotis nigricans & F & insectivorous & \\
\hline & & & São Paulo & Tadarida brasiliensis & $\mathrm{F}$ & insectivorous & \\
\hline & & & São Paulo & Nyctinomops macrotis & M & insectivorous & \\
\hline & & & Votuporanga & Artibeus lituratus & $\mathrm{F}$ & frugivorous & \\
\hline & & & São Paulo & Nyctinomops macrotis & M & insectivorous & \\
\hline & & & Jundiaí & Nyctinomops laticaudatus & F & insectivorous & \\
\hline & & & São Paulo & Nyctinomops macrotis & $\mathrm{F}$ & insectivorous & \\
\hline & & & Cotia & Lasiurus ega & M & insectivorous & \\
\hline & & & Jundiaí & Eptesicus sp & $\mathrm{F}$ & insectivorous & \\
\hline
\end{tabular}

Total $\quad 5,670 \quad 44$

F: female, M: male. 
TABLE 2 - Rabies antibodies prevalence in bats according to year and food preference, City of São Paulo, Brazil, 1992-2003.

\begin{tabular}{|c|c|c|c|c|c|c|}
\hline \multirow[b]{2}{*}{ Year } & \multicolumn{5}{|c|}{ Food prevalence } & \multirow[b]{2}{*}{ Prevalence (\%) } \\
\hline & insectivorous & phytophagous & hematophagous & not identified & total & \\
\hline $1992-1995$ & 83 & 28 & 0 & 0 & 111 & 9.9 \\
\hline 1996 & 218 & 25 & 0 & 5 & 248 & 2.8 \\
\hline 1997 & 259 & 21 & 6 & 8 & 294 & 3.7 \\
\hline 1998 & 124 & 64 & 5 & 13 & 206 & 3.9 \\
\hline 1999 & 100 & 39 & 17 & 59 & 215 & 2.8 \\
\hline 2000 & 62 & 32 & 11 & 23 & 128 & 2.3 \\
\hline 2001 & 54 & 13 & 6 & 2 & 75 & 10.7 \\
\hline 2002 & 128 & 24 & 9 & 12 & 173 & 23.1 \\
\hline 2003 & 102 & 45 & 14 & 7 & 168 & 1.8 \\
\hline Total & 1,130 & 291 & 68 & 129 & 1,618 & 6.7 \\
\hline
\end{tabular}

samples). Prevalence according year and food preference of bats is presented in Table 2. Among the 96 reagent sera, only three bats were positive for FAT and MIT techniques (three bats of the species H. velatus in 2002).

Among the 1,618 bats submitted to rabies serology, $65.8 \%$ of them were captured in the City of São Paulo and $34.2 \%$ in other cities in the State of São Paulo.

Predominance of insectivorous bats (69.8\%) was observed every year throughout the period. Phytophagous (nectarivorous and frugivorous) represented $18 \%$ and hematophagous bats represented $4.2 \%$. Thirty species of bats were identified and the insectivorous bat Molossus molossus (51.8\%) was predominant. Rabies antibody prevalence according species is presented in Table 3.

Distribution according sex confirmed 62 out of 896 females and 34 out of 559 males with rabies antibody titers. For 163 specimens this information was not available. Throughout the entire period, the number of females was higher than males; however, this difference was not significant $\left(x^{2}=0.39\right.$; $\mathrm{p}=0.05)$. Seroprevalence was $6.9 \%$ among females and $6.1 \%$ among males.

\section{DISCUSSION}

The conditions of big cities seem appropriate for the permanence of bats, given the lack of predators, large quantities of food and adequate shelters. These factors are common in urban ecosystems. In this work, insectivorous bats from Molossidae and Vespertilionidae families represented the majority of the sample. This was expected, because urban ecosystems, like the City of São Paulo, are especially favorable to insectivorous bats due to the large population of insects attracted to this type of environment by street lamp illumination ${ }^{10}$.

In the majority of the 44 positives cases, bats were found in the morning, inside houses or commercial buildings or on the ground. Eighteen per cent of the bats captured in yards or buildings in South Carolina (USA) in the period 1970-1990, were positive for rabies ${ }^{11}$.
TABLE 3 - Rabies antibodies prevalence in bats according to species identification, City of São Paulo, Brazil, 1992-2003.

\begin{tabular}{|c|c|c|c|c|}
\hline Family & Species identification & Total & $\begin{array}{c}\text { Reagents } \\
\text { number }\end{array}$ & $\begin{array}{c}\text { Prevalence } \\
\%\end{array}$ \\
\hline \multirow[t]{15}{*}{ Molossidae } & Cynomops planirostris & 1 & 0 & 0.0 \\
\hline & Eumops auripendulus & 30 & 2 & 6.7 \\
\hline & Eumops glaucinus & 6 & 0 & 0.0 \\
\hline & Eumops perotis & 13 & 1 & 7.7 \\
\hline & Eumops sp. & 1 & 0 & 0.0 \\
\hline & Molossops neglectus & 2 & 0 & 0.0 \\
\hline & Molossus molossus & 839 & 27 & 3.2 \\
\hline & Molossus rufus & 42 & 1 & 2.4 \\
\hline & Molossus sp. & 6 & 1 & 16.7 \\
\hline & Nyctinomops aurispinosus & 1 & 0 & 0.0 \\
\hline & Nyctinomops laticaudatus & 16 & 2 & 12.5 \\
\hline & Nyctinomops macrotis & 23 & 3 & 13.0 \\
\hline & Promops nasutus & 5 & 0 & 0.0 \\
\hline & Tadarida brasiliensis & 48 & 3 & 6.3 \\
\hline & Eptesicus brasiliensis & 13 & 0 & 0.0 \\
\hline \multirow[t]{7}{*}{ Vesperstilionidae } & Eptesicus furinalis & 1 & 0 & 0.0 \\
\hline & Histiotus velatus & 60 & 16 & 26.7 \\
\hline & Lasiurus cinereus & 2 & 0 & 0.0 \\
\hline & Lasiurus ega & 2 & 0 & 0.0 \\
\hline & Lasiurus sp. & 2 & 0 & 0.0 \\
\hline & Myotis albescens & 1 & 0 & 0.0 \\
\hline & Myotis nigricans & 16 & 0 & 0.0 \\
\hline Total insectivorous & & 1,130 & 56 & 4.9 \\
\hline \multirow[t]{6}{*}{ Phyllostomidae } & Artibeus fimbriatus & 4 & 0 & 0.0 \\
\hline & Artibeus lituratus & 54 & 5 & 9.3 \\
\hline & Artibeus obscurus & 1 & 0 & 0.0 \\
\hline & Carollia perspicillata & 9 & 3 & 33.3 \\
\hline & Platyrrhinus lineatus & 66 & 2 & 3.0 \\
\hline & Sturnira lilium & 17 & 2 & 11.8 \\
\hline \multirow[t]{4}{*}{ Total frugivorous } & & 151 & 12 & 7.9 \\
\hline & Anoura caudifer & 6 & 0 & 0.0 \\
\hline & Anoura geoffroyi & 1 & 0 & 0.0 \\
\hline & Glossophaga soricina & 133 & 14 & 10.5 \\
\hline \multirow[t]{3}{*}{ Total nectarivorous } & & 140 & 14 & 10.0 \\
\hline & Desmodus rotundus & 66 & 8 & 12.1 \\
\hline & Diphylla ecaudata & 2 & 0 & 0.0 \\
\hline \multirow[t]{2}{*}{ Total hematophagous } & & 68 & 8 & 11. \\
\hline & Without identification & 129 & 6 & 4.6 \\
\hline Total & & 1,618 & 96 & 5.9 \\
\hline
\end{tabular}


In disagreement with Hester et $\mathrm{al}^{12}$, who reported that rabies prevalence in solitary species submitted for rabies diagnosis in the USA and Canada is consistently greater than in colonial species, even though the largest number of rabies cases were determined in the colonial bat Eptesicus fuscus, in this work, only six of the rabiespositive bats were from solitary species. In our sample, prevalence seems be more directly related to species habit in urban areas, which use cramped locals as shelter with intense body contact among individuals, than solitary or colonial species.

It is likely that some of the bats detected as rabies-positive were sent for rabies diagnosis and species identification because the people who found them had some knowledge concerning the potential risk involving bats and rabies transmission. Bats collected by the public are often sick or injured and therefore represent a biased subpopulation of bats more likely to be infected with rabies, such that rabies prevalence tends to be higher ${ }^{11,13,14}$. In studies where presumed healthy bats captured during flight were screened for the rabies virus, prevalence is consistently reported as less than $2 \%^{12}$.

Every day the CCZ-SP receives complaints from citizens in relation to bats, citing the noise, the smell of urine and excrement they produce or simply their presence. The population has been oriented continually not to handle these animals and to communicate with the health authorities when a bat is found in an atypical situation, such as flying during the day, paralyzed or moribund, incapable of flying or exposed to sunlight. At the CCZ-SP, information regarding rabies and bats has been publicized for more than 20 years, but to the public, the ecological role of these animals remains largely unknown and public opinion concerning them is generally based on prejudice, fear and erroneous concepts.

The prevalence of the rabies virus observed in this study (0.8\%) may not be representative of the reality of the bat population in urban areas, because the majority of the bats were received due to citizens' complaints (passive surveillance). However, other reports in the State of São Paulo showed similar prevalence in bats: $1.2 \%$ in the northwestern region from 1993 to $2007^{15}, 1.3 \%$ in the northern and northwestern areas from 1997 to $2002^{16}$ and 1.6 in the western region from 1996 to $2003^{17}$.

While in other regions of the State of São Paulo, the most common species confirmed with rabies were the frugivorous bat A. lituratus and the insectivorous bats M. nigricans ${ }^{15,16}$, in this work, four species predominated: T. brasilienses $(19.2 \%)$ H. velatus (15.9\%), N. macrotis (13.6\%) and A. lituratus (13.6\%), while M. nigricans represented $9.1 \%$. Regarding $H$. velatus, five of the six positive cases were found in one colony in $2001 / 2002^{18}$.

An increase in the number of bats forwarded for diagnosis in this laboratory has been observed since 1989 and this could be the outcome of an increase in the bat population in urban areas due to the degradation of their natural areas, as well as the publicizing and divulgation of positive rabies cases. The increase in the number of cases of rabies-positive bats registered mostly reflects the increasing interest concerning the disease than any real increase in disease incidence ${ }^{19}$.

Rabies infections of bats can occur during interspecies interaction, possibly by sharing shelters. In nature, bites among bats, the main mechanism of rabies transmission, are frequently observed; although rabies virus in bats involves a variety of transmission and maintenance mechanisms in addition to biting: aerosols ${ }^{20}$, drinking milk infected with rabies virus ${ }^{21}$, transplacental transfer and prenatal infection $^{13,22}$.
Low rabies virus prevalence in bats associated with higher rabies antibody prevalence has been reported in the literature. Few studies exist concerning rabies seroprevalence in bats and in these studies the prevalence has shown extensive differences in the results, between $2.2 \%$ and $80 \%$. The presence of rabies antibodies has been detected by different serological techniques in numerous bats species, collected in their habitats or in urban shelters ${ }^{23-27}$.

Price \& Everard ${ }^{23}$ observed seroprevalence of $8.6 \%$ in 439 sera samples. The highest prevalence (29.4\%) was observed in Artibeus planirostris (formerly A.jamaicensis). Steece \& Altenbach ${ }^{13}$ reported antibodies in 514 of 750 sera of Tadarida brasiliensis. Aghomo et $\mathrm{al}^{24}$ verified rabies antibodies in five out of 50 frugivorous bats Eidolon helvum (10\%) from Nigeria, Africa. Jiang et $\mathrm{a}^{26}$ tested for rabies antibodies in sera from 685 bats of eight species from China and the total seroprevalence was $2.2 \%, 2.3 \%$ for frugivorous bats and $1.8 \%$ for insectivorous bats.

Shankar et $\mathrm{al}^{28}$ detected VNA in five $(14.3 \%)$ out of 35 insectivorous bats Eptesicus fuscus and Salas-Rojas et $\mathrm{al}^{25}$ examined 151 sera from nonhematophagous bats of 16 species and the seroprevalence determined was $37 \%$. VNA were determined in 12 nonhematophagous bat species. The three species with the largest sample size and prevalence were Artibeus planirostris (formerly named A. jamaicensis) (14/34), Sturnira lilium (14/37) and Glossophaga soricina $(8 / 20)$.

The high prevalence of rabies antibodies observed in this study in insectivorous bats Histiotus velatus is related to one colony of 42 bats, in which five rabies-positive cases were detected (12\%). Thirty-eight sera were collected and 16 presented antibody titers above $0.5 \mathrm{IU} /$ $\mathrm{ml}$. Elevated seropositivity with high titers, like that observed in this colony, demonstrates a recent outbreak ${ }^{18}$.

Regarding C. perspicillata and G. soricina, the presence of rabies antibodies could be related to the fact that these species share shelters with $D$. rotundus, a species frequently involved in rabies cases in Brazil; however, each species has their own niche inside the shelter with no interspecies relation. A. lituratus are colonial frugivorous bats that show aggressive behavior. At the CCZ-SP, these bats are frequently observed with visible scars on the wings compatible with bites, the main mechanism for rabies virus transmission. Bats Nyctinomops laticaudatus, Nyctinomops macrotis and Tadarida brasiliensis are colonial species that use cramped locations as shelters in urban areas, with intense body contact among individuals; this fact could also be associated with rabies virus transmission and the presence of antibodies.

The high prevalence of rabies antibodies in bats and other wild animals associated with low prevalence of rabies virus has been explained in different ways: exposure to rabies virus shortly after birth ${ }^{13}$; subclinical or asymptomatic infections ${ }^{13,29,30}$; sublethal infection ${ }^{31-33}$; carrier state ${ }^{34}$; and latent virus activated by stress ${ }^{30-31,35,36}$.

Turmelle et $\mathrm{al}^{27}$ investigated whether roost type (natural or artificial) was a significant predictor of rabies seroprevalence in insectivorous bats Tadarida brasiliensis. They expected lower immune competence from bats in artificial roosts because of the perceived stresses associated with anthropogenic disturbances. However, while roost type alone was not a significant predictor of rabies seroprevalence, seasonal fluctuations in seroprevalence were affected by roost type. Increased seroprevalence after parturition in cave colonies, related to an influx of susceptible young, was also observed, as well as more uniform seroprevalence in artificial colonies. 
Regarding the influence of stress, as measured by the maintenance of the rabies virus in bat colonies of Desmodus rotundus, Dimitrov et $\mathrm{al}^{37}$ investigated its effects by analysing its influence on population densities and immunological profile of the colonies. The conclusion was that an accidental stressful event can be easily overcome by the population, while a persistent vertical immunodepression due to stress factors can have a devastating impact on the colony, even if it occurs at relatively low rates, and that seasonal stress factors affect population dynamics, but do not significantly alter the immunological profile of the colony.

Shankar et $\mathrm{al}^{28}$ observed seroconversion in four bats during the period of captivity and concluded that fatal rabies virus infections may not be common among bats despite established stable infection cycles via bites, while immunity may be acquired through recurrent exposure to rabies virus during close contact between individuals. Intraspecies spread of rabies may cause acute disease in some bats, while in others an abortive infection may result in seroconversion.

The predominance of females over males observed in this study was also reported by Burnett ${ }^{38}$ and Childs et $\mathrm{al}^{39}$. However, this difference regarding sex was not observed by others authors ${ }^{12,15,16}$. In some species, females live in maternity colonies segregated from the males. This fact suggests that females are more easily captured in relation to males, who live in small groups or in various shelters and locations or are segregated from the colony by dominant males. Moreover, due to pregnancy and pups, females become heavier and, consequently, are easier to capture in the shelter. On the other hand, males fight viciously for access to the top of hierarchy in the colony or for preferred roosting females ${ }^{40}$, which would provide the opportunity for rabies transmission.

The expressive levels of antibodies verified in these bats indicate that rabies virus circulates actively among them, causing continuous viral challenge and, as a consequence, many of them are protected from the disease and rabies virus prevalence is low. The existence of rabid bats in areas where rabies has not been notified represents a potential risk of rabies infection for humans and domestic animals, especially when these bats are found inside houses or commercial buildings, as reported in this paper. However, biologists and health authorities need to ensure that this risk does not endanger conservation efforts for these mammals.

\section{CONFLICT OF INTEREST}

The authors declare that there is no conflict of interest.

\section{REFERENCES}

1. Velasco-Villa A, Orciari LA, Juárez-Islas V, Gómez-Sierra M, Padilla-Medina I, Flisser A, et al. Molecular diversity of rabies viruses associated with bats in Mexico and other countries of the Americas. J Clin Microbiol 2006; 44:1697-1710.

2. Schneider MC, Romijn PC, Uieda W, Tamayo H, da Silva DF, Belotto A, et al. Rabies transmitted by vampire bats to humans: An emerging zoonotic disease in Latin America? Rev Panam Salud Publica 2009; 25:260-269.

3. Messenger SL, Smith JS, Rupprecht CE. Emerging epidemiology of batassociated cryptic cases of rabies in humans in the United States. Clin Infect Dis 2002; 35:738-747.

4. Favi M, Mattos CA, Yung V, Chala E, López LR, Mattos CC. First Case of Human Rabies in Chile Caused by an Insectivorous Bat Virus Variant. Emerg Infect Dis 2002; 8:79-81.

5. Pan-American Health Organization. World Health Organization [Internet]. Database 2009. [cited 2010 oct 13] Available from http://siepi.panaftosa.org. br/anuais.aspx and http://sirvera.panaftosa.org.br.
6. Sodré MM, Gama AR, Almeida MF. Updated List of bat species positive for rabies in Brazil. Rev Inst Med Trop Sao Paulo 2010; 52:75-81.

7. Dean DJ, Abelseth MK, Atanasiu P. The fluorescent antibody test. In: Meslin FX Kaplan MM, Koprowisk H, editors. Geneva: Laboratory techniques in rabies; 1996. p. 80-87.

8. Koprowisk H. The mouse inoculation test. In: Meslin FX, Kaplan MM, Koprowisk H, editors. Geneva: Laboratory techniques in rabies; 1996. p. 88-96.

9. Smith JS, Yager PA, Baer GM. A Rapid Reproducible test for determining rabies neutralizing antibody. Bull WHO 1973; 48:535-541.

10. Rydell J, Racey PA. Street lamps and the feeding ecology of insectivorous bats. Symp Zool Soc London 1995; 67:291-307.

11. Parker EK, Dowda H, Redden SE, Tolson MW, Turner N, Kemick W. Bat rabies in South Carolina, 1970-90. J Wildl Dis 1999; 35:557-563.

12. Hester LC, Best TL, Hudson MK. Rabies in Bats from Alabama. J Wildl Dis 2007; 43:291-299.

13. Steece RS, Altenbach JS. Prevalence of rabies specific antibodies in the Mexican free-tailed bat (Tadarida brasiliensis mexicana) at Lava cave, New Mexico. JWildl Dis 1989; 25:490-496.

14. Liesener AL, Smith KE, Davis RD, Bender JB, Danila RN, Neitzel DF, et al. Circumstances of bat encounters and knowledge of rabies among Minnesota residents submitting bats for rabies testing. Vector Borne Zoonotic Dis 2006; 6:208-215

15. Queiroz LH, Carvalho C, Buso DS, Ferrari CIL, Pedro WA. Perfil epidemiológico da raiva na região Noroeste do Estado de São Paulo no período de 1993 a 2007. Rev Soc Bras Med Trop 2009; 42:9-14.

16. Cunha ESM, Silva LHQ, Lara MCCSH, Nassas AFCN, Albas A, Sodré MM, et al. Bat rabies in the north-northwestern regions of the State of São Paulo, Brazil: 1997-2002. Rev Saude Publica 2006; 40:1082-1086.

17. Albas A, Zoccolaro PT, Rosa TZ, Cunha ESM. Laboratory diagnosis of rabies in the west region of São Paulo state. Rev Soc Bras Med Trop 2005; 38:493-495.

18. Martorelli LFA, Almeida MF, Durigon EL. Rabies in a bat colony of Histiotus velatus, São Paulo City, Brazil. XIII International Meeting on Research Advances and Rabies Control in the Americas. Mexico; 2002. p. 60-61.

19. Steece RS, Erickson TJ, Siem RA. Chiropteran rabies in Minnesota: 1976-1980. J Wildl Dis 1982; 18:487-489.

20. Constantine DG. Rabies transmission by air in bat caves. Public Health Rep $1967 ; 82: 867-888$.

21. Constantine DG, Tierkel ES, Kleckner MD, Hawkine DM. Rabies in New Mexico caverns bats. Public Health Rep 1968; 83:303-316.

22. Steece RS, Calisher CH. Evidence for prenatal transfer of rabies virus in the Mexican free-tailed bat (Tadarida brasiliensis mexicana). J Wildl Dis 1989; 25:329-334.

23. Price JL, Everard COR. Rabies virus and antibody in bats in Grenada and Trinidad. J Wildl Dis 1977; 13:131-134.

24. Aghomo HO, Ako-Nai AK, Oduye OO, Tomori O, Rupprecht CE. Detection of rabies virus antibodies in fruit bats (Eidolon helvum) from Nigeria. J Wildl Dis 1990; 26:258-261.

25. Salas-Rojas M, Sanchez-Hernandez C, Romero-Almara ML, Schnellc GD, Schmida RK, Aguilar-Setien A. Prevalence of rabies and LPM paramyxovirus antibody in non-hematophagous bats captured in the Central Pacific coast of Mexico. Trans R Soc Trop Med Hyg 2004; 98:577-584.

26. Jiang Y, Wang L, Lu Z, Xuan Z, Han X, Xia X, et al. Seroprevalence of Rabies Virus Antibodies in Bats from Southern China. Vector Borne Zoonotic Dis 2009; Published online: 3 June 2009; doi: 10.1089=vbz.2008.0212.

27. Turmelle AS, Allen LC, Jackson FR, Kunz TH, Rupprecht CE. Ecology of Rabies Virus Exposure in Colonies of Brazilian Free-Tailed Bats (Tadarida brasiliensis) at Natural and Man-Made Roosts in Texas. Vector Borne Zoonotic Dis March 2010, 10:165-175.

28. Shankar V, Bowen RA, Davis AD, Rupprecht CE, Shea T. Rabies in a Captive Colony of Big Brown Bats (Eptesicus fuscus). J Wildl Dis 2004; 40:403-413

29. Hill RE, Beran GW, ClarkWR. Demonstration of rabies virus-specific antibody in the sera of free-ranging Iowa raccoons (Procyon lotor). J Wildl Dis 1992; 28:377-385.

30. Greenwood RJ, Newton WE, Pearson GL, Schamber GJ. Population and movement characteristics of radio-collared striped skunks in North Dakota during an epizootic of rabies. J Wildl Dis 1997; 33:226-241. 
31. Mclean RG. Raccoon rabies. In: Baer GM, editor. The natural history of rabies. New York: Academic Press; 1975. p. 53-77.

32. Everard COR, Baer GM, Alls ME, Moore SA. Rabies serum neutralizing antibody in mongooses from Grenada. Trans R Soc Trop Med Hyg 1981; 75:654-666.

33. Gascoyne SC, Laurenson MK, Lelo S, Bomer M. Rabies in African Wild Dogs (Lycaon pictus) in the Serengeti Region, Tanzania. J Wildl Dis 1993 , 29:396-402.

34. East ML, Hofer H, Cox JH, Wulle U, Wiik H, Pitra C. Regular exposure to rabies virus and lack of symptomatic disease in Serengeti spotted hyenas. Proc Natl Acad Sci USA, 2001; 98:15026-15031.

35. Zumpt IF. Factors influencing rabies outbreaks: the age and breeding cycle of the yellow mongoose, Cynictis penicillata. J S Afr Vet Assoc 1969; 40:319-322.

36. Ballard WB, Krausman PR. Occurrence of rabies in wolves of Alaska. J Wildl Dis 1997; 33:242-245.

37. Dimitrov DT, Hallam TG, McCracken GF, editors. Modeling the effects of stresses on dynamics of bat rabies. Proceeding of the second IASTED International Conference Environmental Modeling and Simulation. St. Thomas: US Virgin Islands; 2006. p.117-112.

38. Burnett CD. Bat Rabies in Illinois: 1965 to 1986. J Wildl Dis 1989; 25:10-19.

39. Childs JE, Trimarchi CV, Krebs JW. The epidemiology of bat rabies in New York State, 1988-92. Epidemiol. Infect 1994; 113:51-511.

40. Wilkinson GS. The social organization of the common vampire bat. Behav Ecol Sociobiol 1985; 17:123-134. 